\title{
Wahkohtowin as Paideia
}

\author{
Dan LeBlanc
}

AвSTRACT The Wahkohtowin class was held in Saskatoon throughout early 2014. Wahkohtowin brought together prisoners, students, and professors, in order to critically examine Canada's "justice" system. For the author, participation in this class led to deep learning, or what ancient Greeks called Paideia. This article explores why Wahkohtowin led to deep learning. It concludes that the deep learning was attributable to four factors: the leaders created space for suffering to speak; course participants were racially, culturally, and educationally diverse; the pedagogy was relationally Socratic; and participant reflections were aimed at action, in addition to understanding. Throughout the article, Wahkohtowin is compared with the author's experience of law school in order to highlight why law school courses rarely result in Paideia.

KEYWords community-based learning, legal education, praxis, Indigenization

In 2014, I took my favourite law school course, called "Wahkohtowin." This course took place in the Pleasant Hill neighbourhood of Saskatoon, Saskatchewan. In the Wahkohtowin classroom, we discussed justice in addition to law. To a large extent, the course material derived from participants' lived experiences of the (in)justice of law in Saskatoon. Our class was a diverse bunch. It included Indigenous high school students, members of STR8 UPa community-based organization that provides peer support for former gang members (all of whom have had experience in prison or the criminal justice system)-students from the University of Saskatchewan, and our formal instructors: four scholar-activists, two of whom are editors of this special issue. They have reflected on the course elsewhere (Buhler, Settee, \& Van Styvendale, 2014 and 2015).

Our class met on Wednesdays at noon and each meeting followed an established routine. We began each gathering with bannock and soup; in my view, this was fundamental to the course. After we ate, each participant shared something about their week; through this sharing, we established trust and openness. Next, we again went around the circle, with each student sharing their experience of the topic to be discussed; participants in the class-particularly those from STR8 UP_ often had lived experience of the phenomena in question. We then discussed that day's text. This portion included, for example, members of STR8 UP interpreting legislation, and university students interpreting poems about prisoners' experiences of solitary confinement..

Throughout the course, we studied topics including the regulation of panhandling in Saskatoon, the sentencing of Indigenous people in Canadian criminal court, and the law 
of solitary confinement in Canadian prisons. The course's structure provided a measure of stability as we discussed these difficult topics. It also facilitated trust among our group and encouraged us to share what we knew.

Wahkohtowin is a Cree word, which has been translated to me as meaning "kinship." This kinship expands beyond blood relations. It is a kinship that is formed in time and space. This course presupposed our kinship with — and thus our concern for-those who suffer injustice. It also worked to develop kinship among participants.

The course was successful in developing Wahkohtowin in a way that university classes rarely are: it brought the students together and increased our collective solidarity with those outside of our group. In the classroom, our pedagogy was not only relational; it was also Socratic ${ }^{1}$ and Freirian. ${ }^{2}$ In addition, it was communal and participatory, as opposed to adversarial and competitive.

Wahkohtowin was non-adversarial in the sense that we did not have debates in which one position or "argument" won out against the other and was then acquiesced to by the group, who had seen the logic prevail. Our classroom discussion appeared consensus-based-though uniformity was not forced upon anyone, and we valued the different conclusions reached and maintained.

Dialogue and discourse were not merely features of our methodology; they appeared to be course goals. Dialogue was our means and our end. This focus on dialogue helped participants develop increased interconnectedness, knowledge of each other, and mutual respect. In short, the focus on dialogue helped us develop a sense of kinship or Wahkohtowin.

In our course, the individual's experience was an acceptable basis from which to derive knowledge. Our individual experiences were ripe epistemological soil, and we tilled it together. The course content was individual in addition to communal. Participants did not speak as "someone from prison" or "a law student," but rather as themselves, pulling on their experience in prison or law school. It was about our lived experience of the world, informed by our respective social positions.

We did not pursue objective truth together. In my view, we cannot touch capital-T "Truth" in any event (West, 2000, p. 42). Rather, we explored our experience of the world. We took our experience, rather than a purportedly objective set of conditions in the world, as the starting point.

Our diverse experiences were not merely used to develop a more "well-rounded understanding of the object as a whole"; we used them to understand the variety of experiences of the criminal justice system and matters related to it. Understanding each other's experiences of the world was not a means to an end; it was the end-or an end-of the course.

Finally, this class was aimed at action, work, and improvement of the "justice" system. ${ }^{3} \mathrm{We}$

\footnotetext{
${ }^{1}$ In the sense of critically interrogating our tacit presuppositions about the world and each other.

${ }^{2}$ In the sense that all participants were treated as knowing, thinking Subjects mediated by an Object- the text or phenomena we examined together.

${ }^{3}$ Many of my classmates believed that the system was too corrupted to be saved. For those individuals, the first step to "improvement" was discarding the settler justice system in its entirety.
} 
discussed reforms required to the system, raised funds for an inmate wellness committee, and spoke seriously about the adequacy of possible responses to the ongoing tragedy of missing and murdered Indigenous women. We worked to move from understanding the system to changing the system.

In part for these reasons, I experienced Wahkohtowin as deeply shaking to my understanding of myself as a human in the world. It not only increased my knowledge and efficacy in activist pursuits; it was fundamental to my developing sense of self. I experienced it as Paideia, or deep learning, ${ }^{4}$ as opposed to cheap schooling. It was Paideia in that it caused me to rethink my place in the world, reassess my privilege, ${ }^{5}$ and think more deeply about what it means to be an "ally."

Throughout this paper, I aim to explore why I experienced Wahkohtowin as Paideia and what about it shook my foundations. My contention is that such experience is distinct from what is usually done at law school, where we encounter neither material that teaches us how to die, nor how to live; rather, we regularly learn how to "think like lawyers." I am interested in this dissonance.

I will divide my reflections on Wahkohtowin as Paideia into four sections. First, I will highlight the course's ability to allow suffering to speak, and take seriously the lived experienced of marginalized human beings; such an activity is a fundamental condition of truth, and one rarely met. Second, I will focus on the makeup of the class, including its diversity along lines of race, class, and education level. Third, I will reflect upon the pedagogy of the class: studentfocused, dialogical, and relationally Socratic. Finally, I will speak to the "active" element of the course: encouraging reflection and action, or praxis.

Throughout, I will work to compare and contrast this course with my experience of law school classes - not because law school is typically the antithesis of Wahkohtowin (although that may be arguable), but because it is "where I come from."

\footnotetext{
${ }^{4}$ Paideia is a Greek word that will be explored more fully throughout this paper. However, one meaning of it is "deep learning."

${ }^{5}$ By "privilege," I mean a relative term, which references my position and access to social power against that of others. If some are privileged, it is because they are privileged by society —it has named them as valuable, important, or worthy of concern. No one can make themselves privileged; they can only work to join a social class (such as lawyers) that are already privileged. If some are privileged it means others are "un-privileged," or more properly, oppressed and marginalized, meaning that society (or the privileged therein) has labeled them non-valuable, unworthy of concern, or other such violent categorizations. In particular, I was struck by my privileged ability to choose "activist pursuits," as few issues touch me directly. If I stay quiet and join a law firm, I'm unlikely to experience social rejection and Othering. For some of my Wahkohtowin kin, these are not arm's length pursuits; they are life and death issues to be considered, dismantled, and crushed. A particularly good example of this was our class discussion of missing and murdered Aboriginal women, where many knew persons who were disappeared or murdered.

${ }^{6}$ By "ally," I mean a position that is active in support and resolution, but often takes its direction from outside of itself. It is a position properly taken when one has a secondary, rather than primary, stake in the issue at hand-for example, instances where a non-Indigenous individual wishes to speak of Indigenous sovereignty. In such a case, these activists should not be at "the front" of the fight. Indigenous persons are capable of generating their own content, and generating their own priorities. A non-Indigenous tactician is likely not needed, unless one is requested. I have identified this way on both race and gender matters for some time; I experience it as very difficult to unlearn all that I need to in order to offer nonpaternalistic support, given my privilege, body, and history. Wahkohtowin has caused me to reflect and think more about these things.
} 


\section{Meeting the Enabling Conditions of Truth}

I aim to speak of truth, not only as a set of propositions that correspond to facts and observable phenomena in the world, premised upon falsifiable hypotheses and probabilistic reasoning, but rather, as a way of being in the world - a disposition and a moral stance.

The Marxist philosopher and revolutionary Theodore Adorno said that the condition of truth is to allow suffering to speak. There are two elements of this to be considered for the purpose of Wahkohtowin, where we purport to explore the "justice" system.

First, when the suffering of those most impacted (and arguably most targeted) by the system is silenced, we lack full data to properly understand the phenomena of which we speak. Theirs is a particular perspective on the system: they see it from a different angle, and their telling not only informs us of their experience, but also gives an indication of what "the thing" actually looks like. Their testimony not only tells us about themselves, but about the reality they describe. ${ }^{7}$

Second, allowing suffering to speak is fundamental to truth, in the sense of a disposition or way of being in the world. Allowing suffering to speak is implicitly a particular moral claim about habitually silenced persons and groups. It states that their position(s) are required, in part because adopting truth as a way of life requires solidarity with humans who sufferespecially those who are regularly made to suffer.

We must know their struggles and what they know of the world, because we must first understand what type of world we live in and the range of experiences within it. We must have the courage to look suffering, othering, and marginalization in the face, and continue to live. Our analyses must reflect what we know, and what others know. Those who become vulnerable and are willing to share their reflections do a great service to the listener, even as the listener is of help to the speaker, by validating and believing their story, which may provide strength.

Wahkohtowin provided space to speak; because of the safe space, ${ }^{8}$ some individuals chose to speak of suffering — direct and vicarious. In particular, this information came out in talking circles held as part of the class. My classmates often shared their lived experience of the justice system; the courage and trust shown by my classmates with lived experience of the dark side of our current economic, political, and legal schemes were incredible and humbling. Their sharing enhanced our ability to both find truth and live truth, as a way of being human.

Many examples have stuck with me. I will list some of them here, in order to indicate the

\footnotetext{
${ }^{7}$ This perspective on "truth gathering" is similar to an historic folk story I've heard, aimed at promoting religious pluralism, but applicable here. Three blind men encounter an elephant. Each begins to explore it with its hand, in order to ascertain what type of being it is. The first is holding onto the trunk and describes the elephant to be most like a python, or other large snake. The second is near the torso of the elephant, and describes it as huge and round, most like a rhinoceros. The third is touching the tusk of the elephant, and describes it as hard and static, like stone.

The story is meant to promote the notion that no one of us can see the whole of anything alone. We only touch one part, and this affects what we believe the whole to be. When we are in dialogue with others, we can better understand traits the object possesses - knowing that part of it feels like a snake, part a rhino, and stone, for example. We are not only sharing our experience of the thing. We are sharing what part of the thing is actually like.

${ }^{8}$ The safe space was created by factors including: our sharing food each week, dialogue through circle, guest presenters and leaders who were very open with us, and the selection of those invited to our group.
} 
extent of my experience.

One participant who spent a good amount of time in the custody of Correctional Services Canada was particularly willing to share with the group. In one class, he spoke of an experience with guards-being stripped, blindfolded, tied to a table, and beaten in a room full of them. He knows things about the prison system that that few other people could teach.

Another participant spoke of being transported to Pine Grove, a prison for women located near Prince Albert, Saskatchewan. Upon arrival, she was put into what she called "baby dolls": prison-issued clothing, which looks like what a female child would wear. She did not like it. She spoke of humiliation.

One Wahkohtowin facilitator's childhood best friend's father was a police officer. The facilitator saw what sort of person this officer was, and described him to us as quite violent and sadistic. She saw how her friend was treated. She had inside experience of an officer's home life. Her account was not intended to implicate all police officers; it was to share the story of one police officer and to establish the principle that not all police officers are good people.

A university student participant spoke about the ways in which she encounters racism in her life. She spoke of it affecting her, including others' views of her as a scholar and a future teacher. Racism was pervasive in her life. For her, discussions of racism are not purely academic.

While speaking of missing and murdered Indigenous women, an incredible number of participants had either direct or secondary experience with the "issue." Members of my kin told me that disproportionate rates of violence against Indigenous women makes them afraid to walk alone at night. They feel that they have good reason to be afraid; they suffer because of this.

The experiences shared by others in the group moved the discussion from detached and sanitized to personal, direct, and pressing. We did not speak in generalities; we analyzed experiences. Rather than talking about people, we talked with them.

\section{Distinct from My Law School Experience}

I do not experience law school as a context in which suffering is allowed to speak, however much those who suffer attempt to speak. There are a variety of factors which could contribute to this outcome.

First, few in law school are from the most marginalized communities and people groups. This often means that these communities' experiences of suffering are individualized and are interpreted as less urgent to share. Experiences of suffering are framed as personal problems to be worked through, rather than indicators of systemic problems to be addressed and organized against.

Second, if such suffering does exist, and folks wish to speak about it, the law school community may not be conducive to it. The community is not conducive to telling difficult

\footnotetext{
${ }^{9}$ By direct experience, I mean that the individual knew someone who was missing or murdered. By secondary experience, I mean that the individual knows someone whose friend or family member was disappeared or murdered.
} 
truths, because there is insufficient trust within the community. The lack of trust is partially caused by systemic factors, including the large class sizes and competitive atmosphere. It is also partially caused by interpersonal factors, including the prevalence of "type A" personalities among law students.

Even if trust does exist - as it does between some groups of friends at law school, for example_-the classroom context does not facilitate such truth-telling. The classroom setting is not conducive to truth-telling because it rarely values personal experience as a basis for knowledge, and because there is little time for it, once all of the required cases have been read. These conditions virtually guarantee that suffering will not be allowed to speak at the College.

The open dialogue and safe space at Wahkohtowin fostered the conditions of truth. I heard things that were very uncomfortable for me. I heard things I did not want to hear. I heard things that were very painful, and from which I wanted to look away. It hurts to hear stories of another human being harmed in these ways. Though difficult, hearing from these lived experiences has made me more reflective and critical. Hearing them has done some work to change the political into the personal; now we are talking about my family members.

\section{Kin from Different Places: The Makeup of the Class}

At the time of writing this essay, I am one week away from finishing my second year of law school at the University of Saskatchewan, which is located in Treaty 6 Territory. The $\mathrm{U}$ of S College of Law shares a building with the Native Law Centre. In my two years of law school, no class I've been in has studied Treaty 6. This omission is notable; it is perhaps representative of the College's position on the importance of exploring Indigenous-settler relations throughout the study of law.

Adding to this potential oversight by my College is my own personal lifestyle and life choices. Up to last year, I had no close friends who engaged in Indigenous culture and tradition.

As a result, my knowledge of Indigenous struggles has been informed primarily through books, popular culture, and, recently, Idle No More. Each has shaped my perspective. Notwithstanding the benefit of these sources, my relatively "white" social group led to a position where I principally talk about, rather than to, Indigenous people. Until now, I had never had a peer group, let alone Wahkohtowin, with Indigenous and Indigenized persons.

Being involved in a diverse and Indigenized community helped to shake and reformulate some positions I held. My "new” positions undoubtedly still reflect colonial and racist positions. I imagine I'll spend my whole life trying to dismantle the racism inside of me-it is deep.

Notwithstanding these limitations, through Wahkohtowin I learned about Indigenous beauty, intelligence, and community. While I knew that brilliant Indigenous people existed, I was admittedly surprised to find such intelligence among those in our class who do not have formal education. ${ }^{10}$ The academic skills of inductive and deductive reasoning, as well

\footnotetext{
10 This surprise was not because they were Indigenous; my racism is rarely so overt. Rather, it was because of their relative marginalization as reflected in a lack of education, correlated with a low-income upbringing and difficulty in schooling, which are in turn correlated with being an Indigenized person. I did not expect such academic skill from these folks; I had much to unlearn and relearn.
} 
as analogizing, were evident within them as well. They not only had a lot of "interesting experiences," but could expand from those experiences to ground reasonable positions and perspectives.

I also saw beauty among my kin. The beauty of Indigenous communities is regularly called into question in settler society. ${ }^{11}$ Alternatively, such communities may be fetishized and essentialized by "allies" in settler society. Both appear problematic. I've fallen into both errors in the past. In particular, I saw beauty in our symbolic use of the circle-notably the opening check in, and ending each meeting with handshakes. I noted that these symbolic, seemingly ceremonial acts, affected our community. It changed the way we were community, and represented our relationships. It fostered feelings and dispositions of Wahkohtowin.

The experiences and reflections facilitated by this class have unhoused me (West, 2000, p. 40) and changed the way I think about my place in the world; they have changed the way I think about my role as a settler, Saskatchewan resident, and heir to Treaty 6. Such education amounts to Paideia, rather than the cheap schooling that academic discussions of "Indigenous issues" tend to be.

\section{The Pedagogy of the Classroom}

Wahkohtowin's pedagogy is distinct from most. I experienced it as democratically Socratic, as opposed to teacher-centric Socratism. Whereas the democratic expression of this tradition allows for both teachers and students to interrogate ideas and suppositions together, the latter version involves only the teacher questioning the students. It is presumed that the teacher knows and the student is yet to know. In its democratic form, all have valuable knowledge and things to learn. I often hear that the College of Law uses the Socratic method; if it does, it's the non-democratic form of it.

The ancient Greeks often called the pedagogical method referenced above "the Paideia method." This was partially because of its efficacy in bringing about "deep learning." The Paideia method implies some growth in the intellectual freedom of the participants, as opposed to simple vocational training or acquisitions of knowledge (Davies \& Sinclair, 2014, p. 23). It is also aimed at encouraging dialogue, both as a form, and as a way of being in the world (Davies \& Sinclair, 2014, p. 22).

The democratic method is often difficult to implement on a large scale, as well as among people from disparate social backgrounds (Hoerl, 2007, p. 11). This difficulty derives from the requirement that participants share with each other; in order to share deeply, participants must respect each other and value each other's perspectives and experiences. Also, groups must have a shared language, and social rules must be known in order to access this "democratic group." In this way, the Socratic method may emulate the downfall of Greek "democracy": democracy only exists for persons of a particular class.

Wahkohtowin appears to have overcome some of these problems, and achieved a

\footnotetext{
${ }^{11}$ By settler, I mean all non-Indigenous persons who reside in Canada. By settler society, I mean the cumulative collection of non-Indigenous societies present within Canada. Despite its internal diversity, settler society remains a valid cultural category because Indigenous remains a valid cultural category, and Indigeneity assumes its negative: settler society.
} 
functioning practice of democratic Socratism among folks from a wide variety of backgrounds. The enabling elements for this were love and kinship (Hoerl, 2007, p. 6). We also embodied the fundamental values of Socratic Paideia: friendship and conversation (Hoerl, 2007, p. 18). Values such as love, conversation, and student-initiated discourse are very difficult to attain in a typical law school class. This is perhaps what leads to anti-democratic, though critical, teaching methods being the dominant method at the College of Law.

Wahkohtowin's method of instruction furthered the goals of the class, including dialogue, complex and problematized thinking about the justice system, and mutual respect. True, open dialogue is always radical and shaking. It is arguably more so when it occurs among a group as diverse as ours.

\section{From Paideia to Praxis: Being Humans in the World}

Wahkohtowin went further than analyzing various perspectives on the justice system and the problematic outcomes which that system produces and reproduces. The class discussion regularly moved toward action aimed at mitigating the things we thought undesirable.

The pedagogy of Paideia, coupled with safe space for experiences of suffering to speak and a diverse group of participants, facilitated unique collaborative reasoning and thinking, resulting in nuanced analysis consistent with the lived experience of our members. This resulting analysis was often critical.

As our group was made up of members engaged in the world, attempting to be agentic, our discussion often led to the question "what can we do about it?" Our undertaking was both critical and productive. This is notably distinct from any law school class I've yet been involved in, where productive recommendations generally address only breaches of Stare Decisis. ${ }^{12}$

The emphasis on productive, and activist, work was not so much a shaking element for me, as I have spent a fair amount of time with communities who incline toward improving situations. Rather, Wahkohtowin's shaking element was the radical democratic sentiment embodied in those with lived experience and their allies gathering together to think about solutions and set about building the type of world we endeavor to live in. Such collaboration rarely occurs in either law school or activist circles.

\section{Conclusion}

Wahkohtowin raised issues of class, race, gender, oppression, and colonization, which are pressing and troubling in our times. These axes of oppression and identity are both historically contingent and deeply pertinent to what it means to be a human living in Saskatchewan in the present. These questions must be wrestled with (West, 2004, p. 217). They are fundamental to understanding one's self and one's place within history.

I was confronted with dark parts of myself that I am often unconscious of, including Eurocentric, patriarchal, and elitist dispositions. This means my fight for anti-racism, feminism, and democracy must also take place within me. I have a lot of work to do, if I am to be the

\footnotetext{
12 Stare Decisis is the Latin phrase for the legal doctrine of "precedent."
} 
type of human I would like to be. This acknowledgment does not bar me from working for systemic change; rather, it increases the impetus for me to fight for these things. Wahkohtowin caused me to explore the wilderness inside of me. This was a rare, precious experience of Paideia.

\section{About the Author:}

Dan LeBlanc is a union-side labour lawyer in Regina. He also works alongside prisonersmostly trying to get them out of solitary confinement. At the time of writing, Dan was a law student at the University of Saskatchewan.Email: dan@nordalleblanc.ca

\section{References}

Buhler, S., Settee, P., \& Van Styvendale, N. (2015). "We went in as strangers, and left as friends": Building community in the Wahkohtowin classroom. Engaged Scholar Journal, 1(2), 96-113.

Buhler, S., Settee, P., \& Van Styvendale, N. (2014). Teaching and learning about justice through Wahkohtowin. Annual Review of Interdisciplinary Justice Research, 4, 182-210.

Davies, M., \& Sinclair, A. Socratic questioning in the Paideia method to encourage dialogical discussions. Research Papers in Education, 29(1), 20-44.

Hoerl, A. E. (2007). The limitations of Socratic Paideia. Conference Papers- Southern Political Science Association, Annual Meeting.

West, C. (2000). A grand tradition of struggle. The English Journal, 89(6), 39-44.

West, C. (2004). Democracy Matters: Winning the Fight Against Imperialism. New York, NY: Penguin. 